\title{
Investigation of biomorphological and decorative characteristics of ornamental species of the genus Lupinus $L$.
}

\author{
I.M. Didur ${ }^{1}$, V.M. Prokopchuk ${ }^{2}$, H.V. Pantsyreva ${ }^{3}$ \\ ${ }^{1}$ Dean of the Faculty of Agronomy and Forestry, Candidate of Agricultural Sciences, \\ Associate Professor, Vinnytsia National Agrarian University, Vinnytsia, Ukraine \\ ${ }^{2}$ Candidate of Biology Sciences, Associate Professor, Faculty of Agronomy and Forestry, \\ Vinnytsia National Agrarian University, Vinnytsia, Ukraine \\ ${ }^{3}$ Candidate of Agricultural Sciences, Senior lecturer, Faculty of Agronomy and Forestry, \\ Vinnytsia National Agrarian University, Vinnytsia, Ukraine \\ E-mail: mtv-1985@ukr.net
}

Received: 17.09.2019. Accepted: 17.10.2019

\begin{abstract}
In the Podillya area, the most promising for greening different objects is the Lupine perennis L. and Lupine Polyphyllus Lindl. For creation of modern garden compositions of the park zone of Vinnytsia National Agrarian University the most appropriate are the varieties: Lulu-Russell, Minaret, Albus, Fireworks, which were well adapted to the growing conditions, were practically not affected by pests and diseases, were sufficiently resistant to environmental conditions. According to the flowering phase study, it was found that the highest flowering duration was observed in perennial lupine plants. In determining the suitability of the plants studied by us for their use in landscaping, their assessment of the complex of economic and biological indicators in accordance with the State Methodology of Variety Testing was carried out. Their high score on a set of criteria testifies to the prospect and suitability for cultivation in Podillia conditions, as well as the value for different uses: flower beds, ridges, mixboards, landscape type compositions and their smaller variants imitating natural groups.
\end{abstract}

Key words: Lupinus L; Variety; Hybrid; Flowering time; Biomorphological features; Decorative characteristics; Growing area

\section{Introduction}

Today in the world the problem of enrichment and renewal of the range of ornamental plants is very urgent. All this is caused by both the natural increase in the level of human demands with the development of civilization and the aging of varieties, which have been the focus of attention for a long time. For our country, the urgency of these issues is further enhanced by the fact that the assortment of ornamental plants of the genus Lupinus L., which are used today in Ukraine, is extremely poor in comparison with such assortment in the leading countries of the world. The way to solve this problem is the introduction of new plants, which allows to significantly expand the range of decorative and valuable species, their varieties and enrich the cultivated flora of Ukraine. Promising in this regard are species of lupines, in particular deciduous and perennial, which have long been used not only as forage crops, but also decorative, which are of great interest for floriculture as a valuable source of replenishment of the range of flower and decorative crops.

Ornamental lupine species are ornamental garden crops, but flower growers' interest in these plants is much less than similar in appearance. Decorative lupines are easy to care for. However, today, when trendy gardens (natural, easy care, "lazy") are trending, lupines are gradually regaining popularity. Moreover, these cultures are some of the best siderates.

The introduction into modern production practices of modern varieties/hybrids and their testing will significantly expand the use of perennial and perennial lupines in flower growing and improve the cultivated flora of the Podillya region and Ukraine as a whole.

\section{Materials and Methods}

The study was conducted during the 2016-2018 biennium. Exposure at the site of the department of forestry, landscape, horticulture and viticulture Faculty of Agriculture and Forestry Vinnytsia National Agrarian University. The soil and climatic conditions of the study area are favorable for growing lupines. The soil cover of the study area is represented by gray forest soils, which are characterized by low humus content $-1.97 \%$. The amount of absorbed bases is 1.44 mg-eq. per $100 \mathrm{~g}$ of soil. Hydrolytic acidity of gray forest soils of the study area - $3.44 \mathrm{mg}$-eq. per $100 \mathrm{~g}$ of soil and the $\mathrm{pH}$ of the salt. - 5,1. Soil moisture is due to precipitation, as the groundwater level is at a depth of up to $15 \mathrm{~m}$. Primary introductory testing and appropriate evaluation of the investigated flower and decorative species was carried out using conventional methods in ornamental horticulture and the method of state variety testing. Tested varieties/hybrids of L. Polyphyllus Lindl. - Lulu Russell, Minaret and L. perennis L. - Albus, Feerverk from overseas breeding. Analyzing the national state register of varieties of ornamental species of the genus Lupinus $L$. was not found.

\section{Results and Discussion}

Greening of settlements provides sustainability and ecological efficiency of green spaces in an urbanized environment and plays an important role in the development of a modern city. Lupine, a decorative culture, has been known to mankind since ancient times. Extraordinary beauty of colorful flowers and forms of their inflorescences, cut leaves, compact shrubs, lush flowering, decorative throughout the growing season, unpretentious growth conditions, the possibility of long-term growth in one place without 
transplantation, resistance to damage by disease and damage to flowers and pests should promote frequent use of this crop in landscaping. Lupine have considerable environmental plasticity, which is confirmed by its cultivation in many introductory centers with different natural and climatic conditions of the world.

However, the landscaping of the flower arrangements of the city of Vinnytsia and the Podillia Lupinus L. are not often used. One of the reasons for the underutilization of the lupine culture in the green cities of Podillya is the lack of information about their ecological and biological features and decorative properties in our conditions, the cultivation technology and their variants.

Problems of growing lupines in Ukraine, preserving the decorative properties of this culture and conquering it as one of the main flower areas of the world - should be solved on the basis of scientifically sound perspectives of using extremely valuable culture with further study of their suitability for distribution in our country.

Lupine is an annual, biennial or perennial herb that blooms in white, yellow, blue, cream, pink, purple and red flowers, gathered in large inflorescences. However, perennial lupine varieties are most popular in ornamental horticulture and landscaping. In nature, lupines grow in the Mediterranean and North America. In the world of ornamental horticulture, there are at least 200 species of lupines, among which only four are cultivated: white lupine, narrow-leaved lupine, yellow lupine and perennial lupine. In addition to these species, attention is drawn to the following: variable lupine, perennial lupine, small-leaved lupine, dwarf lupine, nutkan lupine, tree lupine. The L. perennis L. and L. Polyphyllus Lindl. Have gained the most popularity in floriculture, as a decorative crop.

Selection of ornamental species of lupine, including the long-standing and many English scientist J. Russell, whose variety populations of hybrids have become widespread in Ukraine. Today, one-color and multi-color varieties and hybrids are popular. In culture, hybrid varieties of lupines are often grown, such as: Princess Juliana and Apricot. Considerable attention is also paid to the varieties bred by the breeder Russell: Burg Freilin - with white color, Main Schloss - with red-brick tint, a series of undersized vivid hybrids Minaret or Splendid - sortgroup monochrome hybrids and varieties with white or white sail.

It is established that under Podillya conditions lupines are many-leafed and lupines are perennial in life form - herbaceous plants, geophytes, by ecomorph - heliophytes, but easily manifest as heliosciophytes, by hydromorph - mesophytes, by phenorrhythmotype belong to summer-autumn group (Table 1 ).

Watching the growth and development of arts and lupine species studied, varieties and hybrids that are designed to decorate flower beds, landscaping areas through the creation of modern garden compositions. Unlike fodder varieties of domestic breeding, the studied plants look brighter and more spectacular.

Table 1. Biomorphological features and recommendations for the use of ornamental species Lupinus $\mathrm{L}$.

\begin{tabular}{|c|c|c|c|c|c|c|}
\hline \multirow{2}{*}{$\begin{array}{c}\text { Variety/hybr } \\
\text { id }\end{array}$} & \multirow[t]{2}{*}{ Life form } & \multirow{2}{*}{$\begin{array}{c}\text { Type of } \\
\text { vegetation }\end{array}$} & \multicolumn{2}{|c|}{ Plant sizes, cm } & \multirow{2}{*}{$\begin{array}{l}\text { Duration of } \\
\text { flowering, } \\
\text { days }\end{array}$} & \multirow[t]{2}{*}{ Usage Guidelines } \\
\hline & & & height & width & & \\
\hline \multicolumn{7}{|c|}{ L. Polyphyllus Lindl. } \\
\hline Lulu-Rassel & perennial & $\begin{array}{l}\text { summer } \\
\text { green }\end{array}$ & 50 & $20-25$ & 40 & $\begin{array}{l}\text { Flowerbeds, borders, } \\
\text { ridges, arboretum } \\
\text { mixers, rows in the } \\
\text { fruit garden, groups }\end{array}$ \\
\hline Minaret & & $\begin{array}{c}\text { summer- } \\
\text { autumn- } \\
\text { green }\end{array}$ & 50 & $30-35$ & 45 & $\begin{array}{c}\text { Flowerbeds, ridges, } \\
\text { compositions, baskets, } \\
\text { tapeworm background, } \\
\text { border }\end{array}$ \\
\hline \multicolumn{7}{|c|}{ L. perennis $\mathrm{L}$. } \\
\hline Albus & perennial & $\begin{array}{l}\text { summer- } \\
\text { autumn- } \\
\text { green }\end{array}$ & 120 & $40-50$ & 55 & $\begin{array}{l}\text { Tapeworms on the } \\
\text { lawn, groups, } \\
\text { mixborder, curb, } \\
\text { retaining walls, natural } \\
\text { groups, background }\end{array}$ \\
\hline Feerverk & & & 150 & $50-60$ & 60 & $\begin{array}{l}\text { Tapeworms on the } \\
\text { lawn, groups, } \\
\text { mixborders, retaining } \\
\text { walls }\end{array}$ \\
\hline
\end{tabular}

It has been investigated that the ornamentation of plants under new conditions depends on their ability to reproduce the varietal characteristics inherent in them, which is manifested in the external state of the plants and in the nature of the passage of the major phenophases. In order to find out the correspondence of the parameters of the plants to their varietal characteristics in Podillya conditions, biometric parameters of the investigated species of lupine variegated were investigated, which allowed to determine the level of decorative variety and flower productivity. The basic morphometric parameters of plants depended on many factors: weather and climatic conditions of the year, varietal features of plants, vegetation period.

Studying the flowering phase, we thoroughly investigated its dynamics in terms of flowering duration, which is presented in the summary chart (Figure 1). 


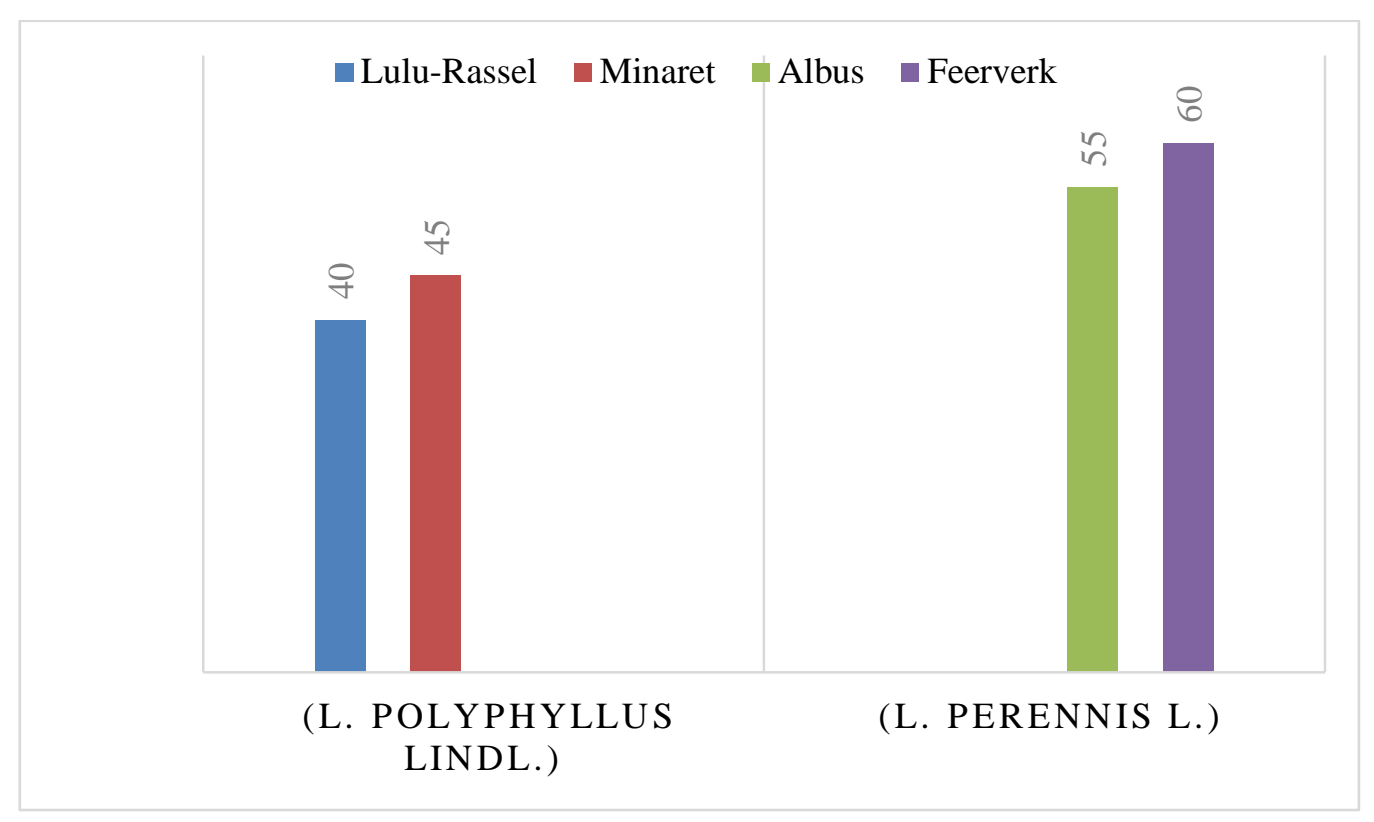

Figure 1. Dynamics of flowering duration of varieties and hybrids of ornamental species of the genus Lupinus $L$., days.

The highest indices of flowering duration (up to 60 days) were recorded in perennial lupine plants (Feerverk - 60 days, Albus - 55 days). Slightly lower rates were observed in lupine (Minaret variety - 45 days, hybrid - Lulu Russell - 40 days).

Studying the biomorphological features of ornamental species of the genus Lupinus $L$., as well as establishing requirements for the decorative qualities of a variety or hybrid sharply increases the value of evaluation and selection of plants by economic and biological indicators - the ability to reproduce, flowering productivity, disease resistance and adverse.

In order to determine the suitability of the plants we study for their use in landscaping, we performed their assessment of a set of economic and biological indicators with the inclusion of some economically significant elements from the system of criteria provided for the evaluation of ornamental (Table 2).

Table 2. Assessment of the decorative value of decorative species of the genus Lupinus L.

\begin{tabular}{|c|c|c|c|c|c|c|c|c|c|}
\hline \multirow{2}{*}{$\begin{array}{l}\text { The name of } \\
\text { the feature }\end{array}$} & \multirow{2}{*}{$\begin{array}{l}\text { Conversion } \\
\text { factors }\end{array}$} & \multicolumn{2}{|c|}{ Lulu Russell } & \multicolumn{2}{|c|}{ Minaret } & \multicolumn{2}{|c|}{ Albus } & \multicolumn{2}{|c|}{ Feerverk } \\
\hline & & $\begin{array}{c}5- \\
\text { mark }\end{array}$ & $\begin{array}{l}100- \\
\text { mark }\end{array}$ & $\begin{array}{c}5- \\
\text { mark }\end{array}$ & $\begin{array}{l}100- \\
\text { mark }\end{array}$ & $\begin{array}{c}5- \\
\text { mark }\end{array}$ & $\begin{array}{l}100- \\
\text { mark }\end{array}$ & $\begin{array}{c}5- \\
\text { mark }\end{array}$ & $\begin{array}{l}100- \\
\text { mark }\end{array}$ \\
\hline $\begin{array}{l}\text { The color of the } \\
\text { flower and its } \\
\text { resistance to } \\
\text { burnout }\end{array}$ & 4 & 5 & 20 & 5 & 20 & 5 & 20 & 5 & 20 \\
\hline $\begin{array}{l}\text { The size of the } \\
\text { flower }\end{array}$ & 1 & 5 & 5 & 5 & 4 & 4 & 4 & 5 & 5 \\
\hline $\begin{array}{l}\text { Inflorescences } \\
\text { (size, density of } \\
\text { flowers, number } \\
\text { of flowers) }\end{array}$ & 4 & 5 & 20 & 4 & 16 & 5 & 20 & 5 & 20 \\
\hline $\begin{array}{l}\text { The quality of } \\
\text { the peduncle }\end{array}$ & 2 & 5 & 10 & 5 & 10 & 5 & 10 & 5 & 10 \\
\hline $\begin{array}{l}\text { Bush (shape, } \\
\text { strength, } \\
\text { decorative) }\end{array}$ & 2 & 5 & 10 & 5 & 10 & 5 & 10 & 5 & 10 \\
\hline Repair & 2 & 4 & 8 & 5 & 10 & 5 & 10 & 4 & 8 \\
\hline $\begin{array}{c}\text { The abundance } \\
\text { of flowering }\end{array}$ & 2 & 4 & 8 & 5 & 10 & 5 & 10 & 5 & 10 \\
\hline Originality & 2 & 4 & 8 & 5 & 10 & 5 & 10 & 5 & 10 \\
\hline $\begin{array}{l}\text { Condition of } \\
\text { plants (equality } \\
\text { of variety) }\end{array}$ & 1 & 5 & 5 & 5 & 5 & 5 & 5 & 5 & 5 \\
\hline Total & & & 94 & & 95 & & 99 & & 98 \\
\hline
\end{tabular}

According to the research, varieties and hybrids of ornamental species of the genus Lupinus L. were well adapted to the growing conditions, practically not affected by disease and were sufficiently resistant to adverse factors. And as the results of the introductory cultivar evaluation show, they deserve a positive assessment for their decorative and economic and biological qualities. 


\section{Conclusion}

Based on the comparative analysis of species and varieties/hybrids of Lupinus L., high scores were obtained on a set of indicators that determine their decorative and economic and biological qualities, the studied plants are evaluated as well adapted to the edaphic and climatic conditions of the Podillya region and recommended as objects for enrichment of an assortment of plants for landscaping, collection and exposition funds, as well as in commercial activity.

\section{References}

Atkins, C. A. (2002). Phenotypic diversity among annual lupins used for crops or having cropping potential. Internat. Conf. on Legumes Genomic and Genetics, Abstracts, 4, 123-140.

Bahmat M. I., Mazur V. A., Didur I. M., Pantsyreva H. V., \& Telekalo N. V. (2018). Bioenergy efficiency of the usage of biopreparations for the growth of white lupine in the conditions of the Right-Bank Forest-Steppe of Ukraine. Ukrainian Journal of Ecology, 8(3): 203-208 (in Ukraine).

Brelles, M, G., \& Boiardi, J. L. (1996). Nitrogen limitation of chemostat-grown Rhizobium etli elicits higher infection-thread formation in Phaseolus vulgaris. Microbiology, 142(5), 1067-1070.

Davis Tim, D., \& Narenda, S. (1986). Soybean photosynthesis and growth as influenced by flurprimidol. Compar Physiology and Ecology, 11(4), 166-169.

Djekoun, A., \& Planchon, C. (1991). Water status effect on dinitrogen fixation and photosynthesis in soybean. Agronomy Journal, 83(2), 316-322.

Dorcinvil, R., Sotomayor-Ramírez, D., \& Beaver, J. (2010). Agronomic performance of common bean (Phaseolus vulgaris L.) lines in an Oxisol. Field Crops Research, 118(3), 264-272. 12. Duke, S. H., \& Collins, M. (1985). Role of potassium in legume dinitrogen fixation. Potassium in agriculture, (potassiuminagri), 443-465.

Elkins, D. M., Hamilton, G., Chan, C. K. Y., Briskovich, M. A., \& Vandeventer, J. W. (1996). Effect of Cropping History on Soybean Growth and Nodulation and Soil Rhizobia 1. Agronomy Journal, 68(3), 513-517.

Mazur, V. A., Mazur, K. V., Pantsyreva, H. V., Alekseev, O. O. (2018). Ecological and economic evaluation of varietal resources Lupinus albus L. in Ukraine. Ukrainian Journal of Ecology, 8(4), 148-153 (in Ukraine).

Mazur, V. A. (2018). Primary introduction assessment of decorative species of the lupinus generation in Podillya. Scientific Bulletin of UNFU, 28(7), 40-43. https://doi.org/10.15421/40280708 (in Ukraine).

Mazur, V. A., Prokopchuk, V. M., \& Pantsyreva, G. V. (2018). Primary introduction assessment of decorative species of the lupinus generation in Podillya. Scientific Bulletin of UNFU, 28(7), 40-43. https://doi.org/10.15421/40280708

Mazur, V. A. \& Pantsyreva, H. V. (2017). Vplyv tekhnolohichnykh pryiomiv vyroshchuvannia na urozhainist i yakist zerna liupynu biloho $v$ umovakh Pravoberezhnoho Lisostepu. Silske hospodarstvo i lisivnytstvo. Vinnytsia, VNAU, Vyp. № 7. T 1, 27-36 (in Ukrainian).

Mazur, V. A., Pantsyreva, H. V., Mazur, K. V., \& Monarkh, V. V. (2019). Ecological and biological evaluation of varietal resources Paeonia L. in Ukraine. Acta Biologica Sibirica, 5 (1), 141-146. https://doi.org/10.14258/abs.v5.i1.5350

Novák, K., Šlajs, M., Biedermannová, E., \& Vondrys, J. (2005). Development of an Asymbiotic Reference Line for Pea cv. Bohatýr

Pantsyreva, H. V. (2017). Formuvannia zernovoi produktyvnosti liupynu biloho zalezhno vid tekhnolohichnykh pryiomiv $v$ umovakh pravoberezhnoho Lisostepu. Dys. na zd. nauk. st. k. s.-h. n. Kam'ianets-Podilskyi, 100-101(in Ukrainian).

Pantsyreva, H. V. (2018). Research of sortal resources of grape species of Paeonia L. in Ukraine. Scientific Bulletin of UNFU, 28 (8), 74-78. https://doi.org/10.15421/40280815 (in Ukrainian).

Pantsyreva, H. V. (2016). Vplyv elementiv tekhnolohii vyroshchuvannia na indyvidualnu produktyvnist roslyn liupynu biloho. Visnyk DDAEU, Silskohospodarska ekolohiia. Ahronomichni nauky. - Dnipro. Vyp. $2.16 \mathrm{~s}$ (in Ukrainian).

Pancyreva, H. V. (2016). Doslidzhennya sortovyx resursiv lyupynu bilogo (Lupinus albus L.) v Ukrayini, 4, 88-93). Vinnycya (in Ukraine).

Sweetingham M. (2008). Lupins reflections and future possibilities. Lupins for Health and Wealth: Proceedings of the 12 th ILCF Western Australia 14-18 September, 514-522.

Vdovenko S. A., Prokopchuk V. M., Palamarchuk I. I., Pantsyreva H. V. (2018). Effectiveness of the application of soil milling in the growing of the squash (Cucurbita pepo var. giraumontia) in the right-benk forest stepp of Ukraine. Ukrainian Journal of Ecology, 8(4), 1-8 (in Ukraine).

Vdovenko, S. A., Pantsyreva, G. V., Palamarchuk, I. I., Lytvyniuk, H. V. (2018). Symbiotic potential of snap beans (Phaseolus vulgaris L.) depending on biological products in agrocoenosis of the right-bank forest-steppe of Ukraine. Ukrainian Journal of Ecology, 8(3), 270-215.

Furseth, B. J., Conley, S. P., \& Ané, J. M. (2011). Soybean response to rhizobia on previously flooded sites in southern Wisconsin. Agronomy journal, 103(3), 573-576.

Furseth, B. J., Conley, S. P., \& Ané, J. M. (2012). Soybean response to soil rhizobia and seed-applied rhizobia inoculants in Wisconsin. Crop science, 52(1), 339-344.

\section{Citation:}

Didur, I.M., Prokopchuk, V.M., Pantsyreva H.V. (2019). Investigation of biomorphological and decorative characteristics of ornamental species of the genus Lupinus L.. Ukrainian Journal of Ecology, 9(3), 287-290.

\begin{tabular}{|ll}
\hline$(c)) \mathrm{EY}$ \\
$\mathrm{Er}$
\end{tabular} 